\title{
Percutaneous Vertebroplasty in Metastatic Thoracolumbar Spine Disease Regarding Pain Relief
}

\author{
AHMED A. ABDELKHALEK, M.D. and AMR A. MOHSEN, M.D. \\ The Department Neurosurgery, Faculty of Medicine, Cairo University
}

\begin{abstract}
Background: Percutaneous vertebroplasty is a minimally invasive technique used for treatment of painful vertebral compression fracture.

Aim of Study: To evaluate the rule of vertebroplasty in treatment of spinal metastasis of thoracolumbar region regarding pain relief.

Patients and Methods: This is a retrospective study of 14 cases of metastatic spinal disease of thoracolumbar region operated upon by percutaneous vertebroplasty between February 2012 to April 2015. Pain intensity was scored on visual analog scale (VAS) pre-operatively and 6 months following surgery to assess improvement. Pre-operative Plain X-ray and MRI of the spine were obtained in all patients as well as serial post-operative X-ray.

Results: 12 patients (85.7\%) of our study showed significant pain improvement within 48 hours of the procedure, at 6 months follow-up 10 patients $(71.4 \%)$ had persistent pain relief. Transient radiculopathy occurred in 1 patient due to cement leakage into the neural foramen.

Conclusion: Percutaneous vertebroblasty is a minimally invasive procedure that is effective in reducing pain in patients with metastatic spinal disease of thoracolumbar spine.
\end{abstract}

Key Words: Veretebroblasty - Pain - Metastatic.

\section{Introduction}

SPINAL metastases account for $5 \%$ of all cancer patients, patients with breast, lung and prostate account for more than $50 \%$ of spinal metastases patients, site of metastasis is $60-80 \%$ in the thoracic spine, $15-30 \%$ in lumbar spine and 10 in cervical spine [4]

About $89 \%$ of spinal metastases are considered of the extradural type, and about $80 \%$ of them occur in the posterior element of the veretebra leading to pain and spinal instability [18]

The main objective for these patients is palliative treatment, the most common presentation is

Correspondence to: Dr. Ahmed A. Abdelkhalek, The Department of Neurosurgery, Faculty of Medicine, Cairo University severe back pain, several modalities were used to alleviate the pain either through medication radiotherapy or surgery. Medications as anti-inflam matory drugs and opioids are used but may be inadequately relieving pain that require bed rest which my increase the risk of pneumonia, deep vein thrombosis and pulmonary embolism [20], Radiotherapy is often the main line of treatment in patients who cannot tolerate surgery, with radiosensitive tumors, or those who have poor prognosis but relieve of pain may take up to two weeks after radiotherapy [19].

Surgery are used for decompression of the spinal cord and in spinal instability, but it is highly invasive with major complications so it is not suitable in spinal metastases patients due to short life expectancy, that is why we used percutaneous vertebroblasty as it is minimally invasive, with use of local anesthesia, less blood loss and less tissue trauma leading to lower morbidity and mortality when compared with open surgery and leading to rapid and efficient pain reduction together with spinal stability [21]

In percutaneous veretebroplasy, pain relief occur due to increase spinal stability, tumor necrosis and tissue necrosis due to the use of polymethyl methacrylate (PMMA) polymerization as it has local cytotoxic and antitumor effect [19]

Aim of study: To evaluate the rule of vertebroplasty in treatment of spinal metastasis of thoracolumbar region regarding pain relief.

\section{Patients and Methods}

This is a retrospective study of 14 cases of metastatic spinal disease of thoracolumbar region operated upon by percutaneous vertebroplasty between February 2012 to April 2015 at Cairo University Hospital.

The procedure was selected for patients with painful vertebral compression fracture affecting 
patient daily activities, in patient who had failed medical treatment.

The patients were 8 females and 6 males, with age 35 to 71 years (average 53 years).

The primary tumors were breast cancer in 6 patients $(43 \%)$, lung cancer in 5 patients $(36 \%)$ and prostate cancer in 3 patients (21\%), 6 patients of our study (43\%) were in the thoracic spine and 8 patients $(57 \%)$ were in the lumbar spine.

\section{Inclusion criteria:}

- Painful vertebral compression fractures that affecting the patient daily activities.

- Intractable pain not responding to medical treatment.

\section{Exclusion criteria:}

- Non painful spinal compression fractures.

- Painful vertebral compression fracture responding to medical treatment.

- Local or systemic infection.

- Allergy to PMMA.

- Tumor compressing the spinal cord.

- Untreated coagulopathy.

All patients with back pain as a main complaint with duration ranging from 28 to 150 days.

Full history taking, general and neurological examination was don for all patients and informed consent was taken.

The pain intensity was recorded by visual analog scale (VAS) was recorded both before, following the procedure, and six months after the procedure, VAS ranging from 0 (no pain) to 10 (worst pain ever).

All patients had preoperative laboratory investigations as complete blood picture, prothrombin time and concentration.

Pre-operative Plain X-ray and MRI of the spine were obtained in all patients as well as serial postoperative X-ray one and six months after the procedure.

Of the 14 patients 11 patients had one level injection and 3 had two level injections

All patients were treated by Vertebroplasty using the percutaneous unilateral (12 vertebra) or bilateral portal ( 5 vertebra) under local infiltration.

Postoperatively All patients had a spinal support for three days with early ambulation next day after the procedure, all patients were discharged the next day after procedure.

Before discharge all patients had chest X-ray, neurological examination with evaluation of pain with visual analogue scale.

Complications as pneumothorax, rib fracture and cement leakage were monitored.

Follow-up at 1,3 and 6 months to asses pain using VAS and X-rays were done to assess the effect of cement on adjacent vertebral levels.

\section{Surgical technique of percutaneous vertebroplaty:}

The patient is positioned prone, using fluoroscopy initial images are acquired to confirm the targeted level a prophylactic dose of broad spectrum antibiotic is given before the procedure, Local anesthesia is then infiltrated into skin, subcutaneous tissues and periosteum, following this an 11 or 13 gauge needle is passed along the anaesthetized tract to penetrate the cortex of veretebra using a transpedicular approach, further images are needed to guide needle placement into anterior quadrant of the targeted vertebral body, ideally as close to midline, bone biopsies can be taken if required, cement is instilled under close imaging until anterior two thirds of the veretebral body is filled and cement is equally distributed on both sides, patients require bed rest for 2 hours under vital and neurological monitoring patients can be mobilized and discharged on the same day.

\section{Results}

In our study 14 cases of metastatic spinal disease of thoracolumbar region operated upon by percutaneous vertebroplasty.

The age of our patients ranging from 35 to 71 years with a mean age of 53 years.

In our study there were 8 females $(57 \%)$ and 6 males $(43 \%), 6$ patients of our study $(43 \%)$ were in the thoracic spine and 8 patients $(57 \%)$ were in the lumbar spine.

Back pain was the main symptom in all cases (100\%) with duration ranging from 28 to 150 days. Intensity of pain using visual analogue scale (VAS) was recorded preoperatively and the mean VAS was 7.3 (range 6 to 10).

The primary tumors were breast cancer in 6 patients $(43 \%)$, lung cancer in 5 patients (36\%) and prostate cancer in 3 patients $(21 \%)$. The mean operative duration in this study was 57.5 minutes, 
with a minimum of 25 minutes and a maximum of 90 minutes.

- The average time for a single level was $28 \mathrm{~min}$.

- The average time for a double level was $38 \mathrm{~min}$.

Of the 14 patients 11 patients (79\%) had one level injection and 3 patients $(21 \%)$ had two level injection, unilateral injections were done in 12 vertebrae $(71 \%)$, and bilateral injections in 5 vertebrae $(29 \%)$.

13 patients $(92.8 \%)$ of our study showed significant pain improvement within 48 hours of the procedure, at 6 months follow-up 12 patients $(85.7 \%)$ had persistent pain relief. Transient radiculopathy occurred in 1 patient due to cement leakage into the neural foramen which resolved after one week.

The mean VAS preoperative was 7.3 (range 6 to 10 ), decreasing to 2.8 after the procedure and to 1.5 at the last follow-up visit.

\begin{tabular}{lccccc}
\hline & Preoperative & $\begin{array}{c}\text { Immediate } \\
\text { postoperative }\end{array}$ & $1 \mathrm{M}$ & $3 \mathrm{M}$ & $6 \mathrm{M}$ \\
\hline Mean VAS & 7.3 & 2.8 & 2 & 1.8 & 1.5 \\
\hline
\end{tabular}

No general complications were found, cement leakage were found in 8 patients (57\%), the leak was noticed in intervertebral disc, needle track or neural foramen.

Postoperative complications in the form of nerve root radiculopathy due to cement leakage in one patient (7\%) which resolved after one week by medical treatment (steroids).

Case 1: Male patient 57 years with primary adenocarcinoma of the lung with vertebral metastasis L2,3, can't move because of severe back pain, after procedure pain markedly improved.

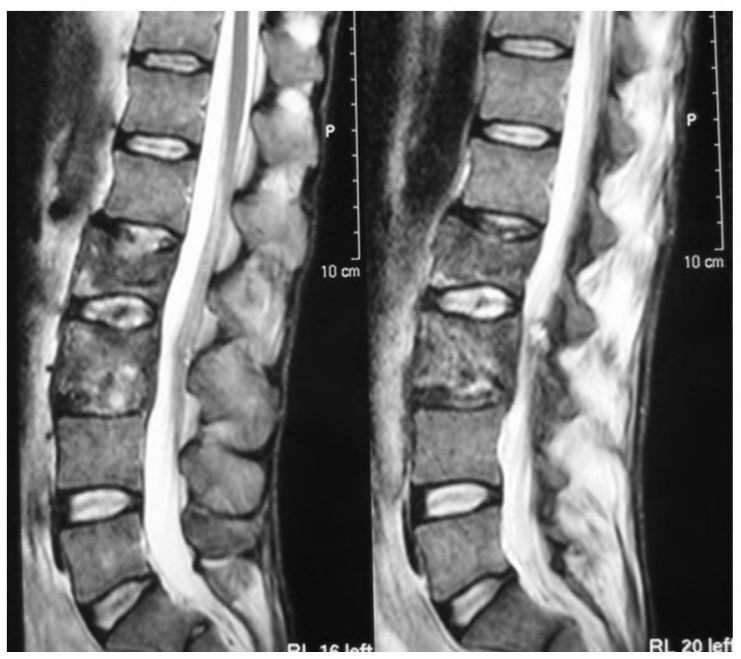

Fig. (1): Preoperative MRI showing L2,3 metastasis.

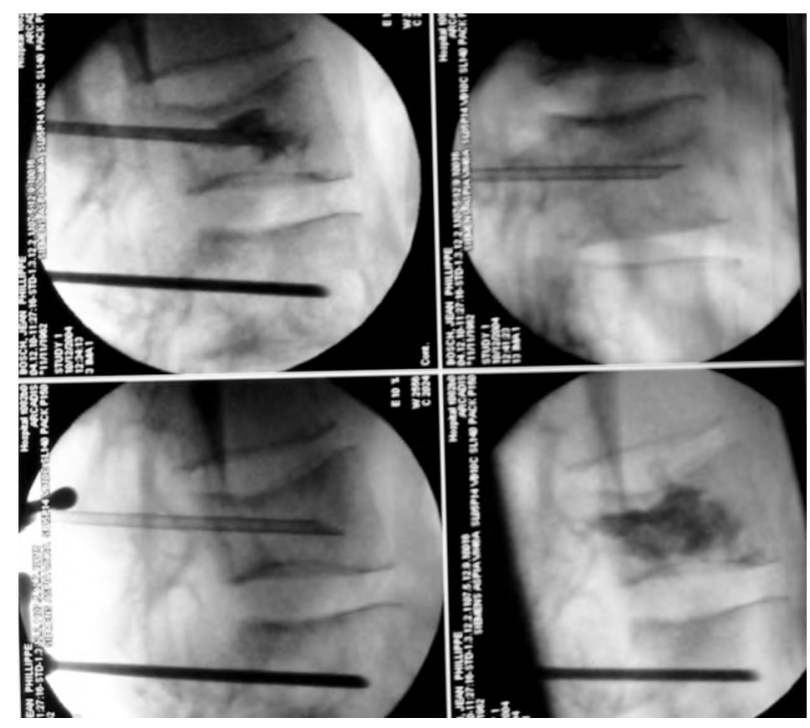

Fig. (2): Intraoperative fluoroscopy during injection.
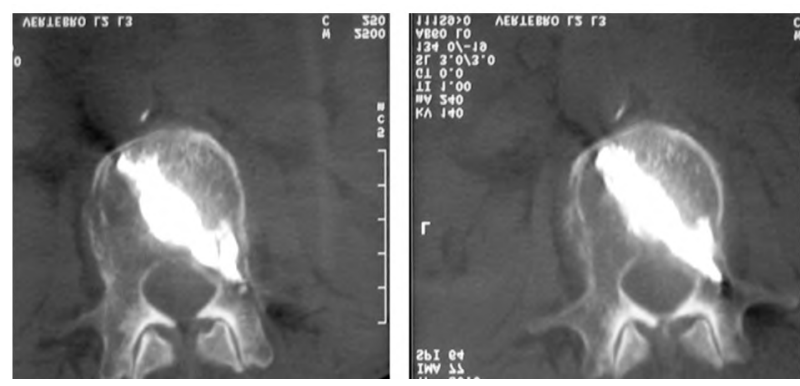

Fig. (3): Postoperative CT.

Case 2: Female patient 60 years, primary breast cancer with D9 metastasis, complaining of severe back pain, showed significant relieve of pain postoperatively.
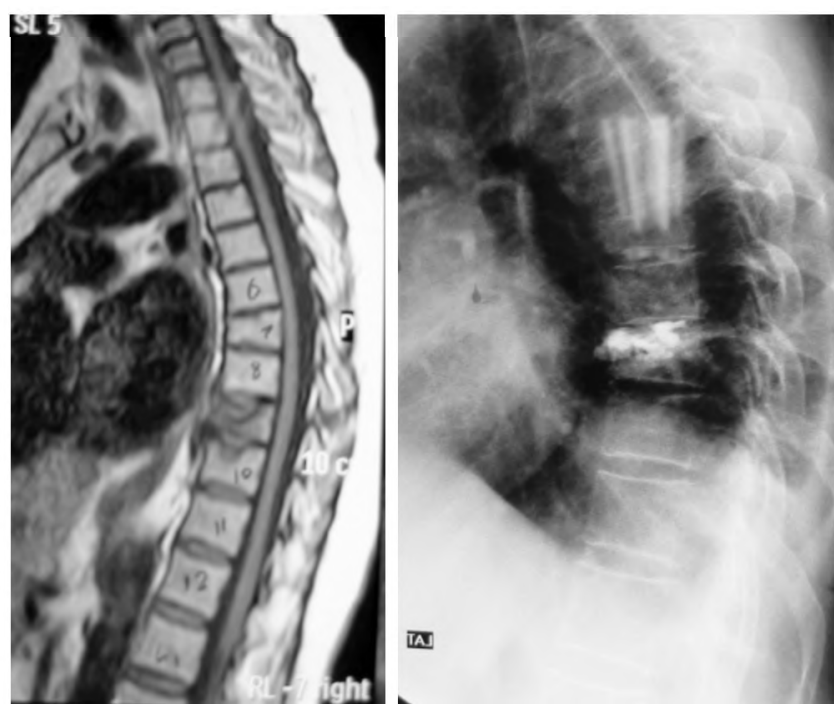

Fig. (4): Preoperative MRI \& Postoperative X-ray. 


\section{Discussion}

Patients with severe back pain due to spinal metastasis can be treated by radiotherapy but its effect as pain relieve may be delayed for up to two weeks or not effective, open surgery can't be done due poor general condition or short life expectancy of patients with metastasis, in our study we used percutaneous vertebroplasty as a minimally invasive procedure alternative to radiotherapy and surgery in reducing pain in those patients [9].

6 patients of our study ( $43 \%)$ were in the thoracic spine and 8 patients (57\%) were in the lumbar spine, also the lumbar spine was the most common site in 6 patients $(75 \%)$ as reported by Alvarez et al., [1] .

During the procedure we used the fluoroscopic guidance both anteroposterior and lateral view to better asses needle progression and cement injection, Cotton et al., [7] also used the fluoroscopy, Barr et al., [2] \& Gangi et al., [13] used a combination of CT and fluoroscopy, David et al., [8], Jensen et al., 1997 recommend the use of venogram to prevent cement leak in the vena cava

Unilateral injections were done in 12 vertebrae (71\%), and bilateral injections in 5 vertebrae (29\%), bilateral injections may be better than unilateral but unilateral injection allow filling of both halves of vertebral body with less operative time.

In our patients the average amount of cement injected was $3 \mathrm{ml}$, Cotten et al., [6]. In addition, Belkoff et al., [3] . have used 2-4ml of cement, Gangi et al., [13] have used $1.5 \mathrm{ml}$ of cement.

The rate of vertebroplasty related complications reported in metastatic disease is $10 \%$ which is higher than when used in osteoporotic patients 2$5 \%$ due to poor general condition and vertebral body destruction in metastatic patients.

In our study cement leakage occurred in 8 patients (57\%) most frequently venous leakage followed by along the needle track, the higher incidence of leakage due to anatomy disruption by tumor extension, Cotten et al., 1998 has $72 \%$ leakage with paravertebral leakage as the most frequent type followed by epidural leakage, Weill et al., [17] reported $38 \%$ leakage.

One patient of our study $(7 \%)$ had nerve root compression radiculopathy due to cement leakage and resolved after one week by medical treatment (steroids), Cotten et al., [7], found nerve root compression that required surgery in two of eight foraminal leakages and transient femoral neurop- athy in one of 21 paravertebral leakages. Depriester et al., [9] found nerve root compression that required surgery in $1.5 \%$ of injections, with radicular symptoms in up to $8 \%$. So if leakage noticed during injection it is important to stop PMMA injection and plane another injection strategy.

Relieve of pain in percutaneous vertebroplasty occur due to increased spine stability, sensory nerve ending destruction and tumor necrosis, tissue destruction occur due to local cytotoxic effect of PMMA, reduction of pain with spinal stability lead to increased activity and better quality of life [21]

13 patients (92.8\%) of our study showed significant pain improvement within 48 hours of the procedure, at 6 months follow-up 12 patients $(85.7 \%)$ had persistent pain relief. Transient radiculopathy occurred in 1 patient due to cement leakage into the neural foramen which resolved after one month.

In our study VAS had reduced from 7.3 preoperatively to 2.8 after the procedure and to 1.5 at the last follow-up visit.

Gangi et al., [13] has $60-85 \%$ significant pain reliever, Deramond et al reported $80 \%$ pain improvement in 101 patients with metastatic spinal disease.

Cortet et al., [5] reported $97 \%$ pain reduction within 48 hours, $89 \%$ at three months and $75 \%$ after 6 months.

Kaemmerlen et al., [14] had used vertebroplasty as an adjuvant to radiotherapy, pain relieve occurred in $85 \%$ in less than 48 hours.

Calmels et al., [12] reported $92 \%$ pain relieve in 6 months follow-up period in his study of 52 patients and Cotten et al., reported $75 \%$ pain relief in his study.

In all studies there were 73 to $100 \%$ pain relief at 6 months follow-up $[\mathbf{1 , 1 0 , 1 2 , 1 4 , 1 5 ]}$, so the result of our study as $85.7 \%$ pain relief at 6 months follow-up in is matching with the other studies, the short follow-up period (six months) is due to the short life expectancy of the metastatic patients.

\section{Conclusion:}

Percutaneous vertebroplasty is a minimally invasive procedure that is effective, safe and rapid in reducing pain in patients with metastatic spinal disease of thoracolumbar spine, so it should be considered the first choice in treating pain in those patients. 


\section{References}

1- ALVAREZ L., ALCARAZ M., PÉREZ-HIGUERAS A., et al.: Percutaneous vertebroplasty: Functional improvement in patients with osteoporotic compression fractures. Spine, 31: 1113-1118, 2006.

2- BARR J.D., BARR M.S., LEMLEY T.J. and McCANN R.M.: Percutaneous vertebroplasty for pain relief and spinal stabilization. Spine, 25: 923-8, 2000.

3- BELKOFF S.M., MATHIS J.M., JASPER L.E. and DIAMOND H.: The biochemical effects of vertebroplasty. The effect of cement value on mechanical behavior. Spine 26: 1537-1541, 2001.

4- COLEMAN R.E.: Metastatic bone disease: Clinical features, pathophysiology and treatment strategies. Cancer. Treat. Rev., 27: 165-176, 2001.

5- CORTET B., COTTON A., BOUTRY N., et al: Percutaneous vertebroplasty in the treatment of osteoporotic vertebral fractures: An open prospective study. J. Rheumatol., 26: 2222-2228, 1999.

6- COTTEN A., DEWATRE F., CORTET B., et al.: Percutaneous vertebroplasty for osteolytic metastases and myeloma: Effects of the percentage of lesion filling and the leakage of methyl methacrylate at clinical follow- up. Radiology, 200: 525-530, 1996.

7- COTTEN A., BOUTRY N., CORTET B., et al.: Percutaneous vertebroplasty: State of the art. Radiographics, 18: 311-320, 1998.

8- DAVID F. KALLMES and MARY E. JENSEN: Percutaneous Vertebroplasty, Radiology, 229: 27-36, 2003.

9- DEPRIESTER C., DERAMOND H., TOUSSAINT P., JHAVERI H.S. and GALIBERT P.: Percutaneous vertebroplasty: Indications, technique, and complications. In: Connors J.J., Wojak J.C. eds. Interventional neuroradiology: Strategies and practical techniques. Philadelphia, Pa: Saunders, 346-357, 1999.

10- DERAMOND H., DARRASON R. and GALIBERT P.: Percutaneous vertebroplasty with acrylic cement in the treatment of aggressive spinal angiomas. Rachis, 1: 143153, 1989, coated from Gangi et al., Percutaneous Vertebroplasty: Indications, Technique, and Results Radiographics, 23: e10-e10, 2003.
11- FOURNEY D.R., SCHOMER D.F., NADER R., et al.: Percutaneous vertebroplasty and kyphoplasty for painful vertebral body fractures in cancer patients. J. Neurosurg., 98: 21-30, 2003.

12- GALIBERT P. and DERAMOND H.: Percutaneous acrylic vertebroplasty as a treatment of vertebral angioma as well as painful and debilitating diseases. Chirurgie, 116: 326334, 1990 .

13- GANGI A., SABHARWAL T., IRANI F.G., BUY X., MORALES J.P. and ADAM A.: Quality assurance guidelines for percutaneous vertebroplasty. Cardiovasc Intervent Radiol., 29: 173-178, 2006.

14- KAEMMERLEN P., THIESSE P., JONAS P., et al.: Percutaneous injection of orthopedic cement in metastatic vertebral lesions. N. Engl. J. Med., 321: 121, 1989.

15- MARTIN J.B., WETZEL S.G., SEIUM Y., et al.: Percutaneous vertebroplasty in metastatic disease: Transpedicular access and treatment of lysed pediclesinitial experience. Radiology, 229: 593-597, 2003.

16- SHIMONY J.S., GILULA L.A., ZELLER A.J and BROWN D.B.: Percutaneous vertebroplasty for malignant compression fractures with epidural involvement. Radiology, 232: 846-853, 2004.

17- WEILL A., CHIRAS J., SIMON J.M., et al.: Spinal metastases: Indications for and results of percutaneous injection of acrylic surgical cement. Radiology, 199: 241247, 1996

18- JACOBS W.B. and PERRIN R.G.: Evaluation and treatment of spinal metastases: an overview, Neurosurg. Focus, Vol. 11, 6pg. e10, 2001.

19- GEORGY B.A.: Metastatic spinal lesions: State-of-theart treatment options and future trends, AJNR. Am. J. Neuroradiol., Vol. 29 (9): p. 1605-1611, 2008.

20- HAMADY M. and SHEARD S.: Role of cementoplasty in the management of compression vertebral body fractures, Postgrad. Med. J., Vol. 85 (1004): p. 293-298, 2009.

21- R.H. KASSAMALI, A. GANESHAN, E.T.D. HOEY, P.M. CROWE, H. DOUIS and J. HENDERSON: Annals of Oncology, Vol. 22: 782-786, 2011. 


\section{حقن الفقرات من خلال الجلد بإستخدام الأسمنت الطبى في الأورام

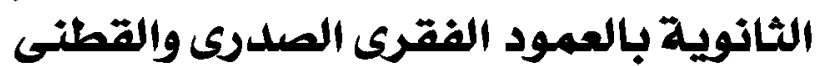 فيما يتعلق بتخفيف الألم المتري}

خلفية: حقن الفقرات من خلال الجلد بإستخدام الأسمنت الطبى هو طريقة محدودة التدخل تستخدم فى علاج آلام كسود العمود الفقرى

$$
\text { الهدف من الدراسهة: تحديد دود حقن الفقرات لعلاج الآلم فى الأقدام الثانوية بالعمود الفقرى الصدرى والقطنى. }
$$

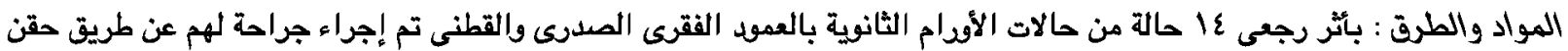

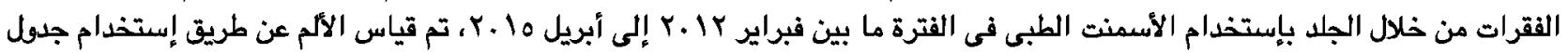

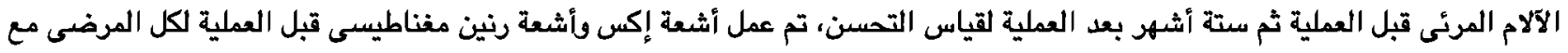
عمل أشعات إكس متتابعة.

النتائج: أثنى عشر مريض ظهر عليهم تحسن للألم فى خلال ثمانية وأربعون ساعة بعد العملية، بعد ستة أشهر عشرة من المرضى أصبح للدهم تصسن مستمر بالألم، آلام عصبية كانت في مريض واحد نتيجة لتسرب الأسمنت الطبى. الخلاصة: حقن الفقرات من خلال الجلد بإستخدام الأسمنت يعتبر طريقة محدودة التذخل لكنها طريقة فعالة فى علاج الألم لمرضى الأمدام

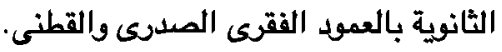

